\title{
Reaction of detached leaves from different varieties of sweet orange to inoculation with Xanthomonas citri subsp. citri
}

\author{
Aline Maria Orbolato Gonçalves-Zuliani ${ }^{1}$, Kátia Aparecida Kern Cardoso ${ }^{2}$, José Belasque Junior ${ }^{3}$, Carlos Alexandre \\ Zanutto $^{1}$, Heraldo Takao Hashiguti ${ }^{1}$, Clive Howard Bock ${ }^{4}$, Celso Vataru Nakamura ${ }^{2}$ and William Mário de Carvalho \\ Nunes $^{1}$
}

${ }^{1}$ Núcleo de Pesquisa em Biotecnologia Aplicada, Universidade Estadual de Maringá, 87020-900, Maringá, Paraná, Brazil, alineorb@hotmail. com, cazanutto@gmail.com, htakaoh@hotmail.com; ${ }^{2}$ Laboratório de Inovação Tecnológica no Desenvolvimento de Fármacos e Cosméticos, Universidade Estadual de Maringá, Maringá, Paraná, Brazil, katiakern@hotmail.com; cvnakamura@gmail.com; ${ }^{3}$ Departamento de Fitopatologia e Nematologia, Escola Superior de Agricultura “Luiz de Queiroz”, Universidade de São Paulo, Brazil; belasque@usp.br; ${ }^{4}$ USDA-ARS-SEFTNRL, 21 Dunbar Road, Byron, GA 31008, USA, clive.bock@ars.usda.gov.

*Corresponding author: William Mário de Carvalho Nunes (wmcnunes@uem.br)

Data de chegada: 19/11/2015. Aceito para publicação em: 15/02/2016.

$10.1590 / 0100-5405 / 2143$

\section{ABSTRACT}

Gonçalves-Zuliani, A.M.O.; Cardoso, K.A.K.; Belasque Junior, J.; Zanutto, C.A.; Hashiguti, H.T.; Bock, C.H.; Nakamura, C.V.; Nunes, W.M.C. Reaction of detached leaves from different varieties of sweet orange to inoculation with Xanthomonas citri subsp. citri. Summa Phytopathologica, v.42, n.2, p.125-133, 2016.

Citrus genotypes show a broad range of resistance to infection with Xanthomonas citri subsp citri $(X c c)$, the causal agent of Asiatic citrus canker (ACC). The aim of this study was to evaluate a detached leaf inoculation method to compare nine different citrus genotypes that exhibit varied resistance levels to ACC, and to evaluate infection, colonization and symptom development of the varieties by using Scanning Electron Microscopy (SEM). Inoculation of Xcc in the leaves was carried out by producing injuries with needles. Lesion diameters were measured at 7, 10 and 13 days after inoculation (DAI). The variety Pera IAC was most resistant to the pathogen and had lesions with smaller diameters, while the variety Washington was most susceptible and had the largest lesions, indicating low resistance to Xcc. SEM images were taken from the lesion development, and sections were obtained from the disease lesions in the tested varieties. The most resistant variety, Pera IAC, had smaller stomatal openings and produced greater quantity of foliar exudates, compared with the variety Washington. We hypothesize that the exudates may contain Xcc toxic compounds and thus may be a defense mechanism against infection by $X c c$, but further research is required to establish any antibiotic effects of the exudates against citrus canker.

Keywords: Citrus canker, Inoculation, Scanning Electron Microscopy (SEM), resistance.

\section{RESUMO}

Gonçalves-Zuliani, A.M.O.; Cardoso, K.A.K.; Belasque Junior, J.; Zanutto, C.A.; Hashiguti, H.T.; Bock, C.H.; Nakamura, C.V.; Nunes, W.M.C. Reação de folhas destacadas de diferentes variedades de laranja doce à inoculação de Xanthomonas citri subsp. citri. Summa Phytopathologica, v.42, n.2, p.125-133, 2016.

Genótipos de citros mostram uma gama de resistência à infecção de Xanthomonas citri subsp. citri $(X c c)$, agente causal do cancro cítrico asiático (ACC). O objetivo deste estudo foi avaliar um método de inoculação em folha destacada para comparar nove genótipos diferentes de citros que apresentam graus de resistência à ACC e, avaliar a infecção, colonização e desenvolvimento de sintomas das variedades utilizando Microscopia Eletrônica de Varredura (MEV). A inoculação de $X c c$ em folhas foi realizada através de ferimentos produzidos com agulhas. Aos 7, 10 e 13 dias após a inoculação (DAI), diâmetros de lesão foram mensurados. A variedade Pêra IAC foi a mais resistente ao patógeno e apresentou lesões com menor diâmetro e a variedade Washington foi a mais suscetível e apresentou as maiores lesões, indicando baixa resistência à Xcc. As imagens de MEV foram feitas no desenvolvimento da lesão, e secções foram cortadas a partir das lesões da doença nas variedades testadas. A variedade mais resistente, Pêra IAC, teve aberturas estomáticas menores e produziram uma maior quantidade de exsudados foliares em comparação com a variedade Washington. Nossa hipótese é que os exsudados podem conter compostos tóxicos de $X c c$ e, portanto, pode ser um mecanismo de defesa para a infecção por $X c c$, embora novas pesquisas são necessárias para estabelecer quaisquer efeitos antibióticos de exsudato contra o cancro cítrico.

Palavras-chave: Cancro cítrico, inoculação, Microscopia Eletrônica de Varredura (MEV), resistência.

Asiatic citrus canker (ACC), caused by Xanthomonas citri subsp. citri (ex Hasse) Gabriel et al. (Xcc), is one of the most damaging diseases of citrus worldwide since it causes direct yield loss (4) and loss in the marketability of fresh fruits. In addition, trade restrictions are often imposed on exporting nations where citrus canker is deemed endemic $(13,26)$. In Brazil, yield loss due to this disease has been 
documented (4), and a previous widely adopted eradication program is currently implemented only in São Paulo State (22). Thus, integrated management of this disease has been developing to minimize the impact of the pathogen $(1,17)$.

Integrated management of citrus canker includes breeding for resistance, as well as identification and use of pathogen-resistant germplasm $(1,7,14,29)$. Studies of different citrus species and varieties have shown that sweet orange [Citrus sinensis (L.) Osbeck] and mandarin (C. reticulata Blanco) exhibit a wide range of resistance to ACC under various conditions and using different inoculation methods $(7,11,14,29,30)$. Differences in varietal reaction among studies might be observed due to experimental conditions, local strains of Xcc or inoculation methods.

$X c c$ naturally penetrates the host tissues through stomata, hydathodes, lenticels or wounds $(5,15,16,27)$. In the absence of visible leaf injury, $X c c$ requires favorable environmental conditions to cause symptoms (1). Experimental evidence suggests that optimal conditions for spray inoculation include temperature between 25 and $30^{\circ} \mathrm{C}$, combined with prolonged leaf wetness (8). Inoculated plants kept at $28^{\circ} \mathrm{C}$ manifested symptoms of the disease after 7 to 10 days (26). Some of the ultra-structural changes associated with symptom development that occur in the host plant as a result of wounding and infection have been described (21). In breeding programs, early detection of ACC symptoms is important as it can increase efficiency by establishing susceptibility (or resistance) as early as possible in the screening or diagnostic process. Although field screening has been used to detect resistant germplasm $(7,14,29)$, it has the disadvantage of being time-, space- and labor-consuming. On the other hand, greenhouse and labbased methods have been considered an alternative $(1,16)$. Inoculation of Citrus plant material combined with needle-wounding has been used to compare the susceptibility of germplasm $(2,14)$. Wounding allows $X c c$ to overcome physical barriers that might impair the pathogen entry through stomata (10), including any resistance conferred by the developing cuticle (18). Reports have suggested that a secondary resistance can occur subcuticularly in the mesophyll in the absence of visible injury (28). Thus, needle-wounding directly deposits inoculum into the leaf and provides an ultimate challenge to resistance prevailing within the leaf in the developmental stage at the time of inoculation. Inoculum concentration must be standardized to realistically compare germplasm (whether wounded or not), and research has suggested that $10^{6}$ to $10^{8} \mathrm{CFU} / \mathrm{mL}$ is an effective concentration to challenge the host when using a needle-wounding screening method $(2,14)$. Once the symptoms develop, they must be appropriately assessed. Lesion diameter is a method used to assess the severity of ACC for resistance screening and in epidemiological studies (14).

The assessment of ACC resistance under partially or fully controlled greenhouse or laboratory conditions (for example, needle-wounding inoculation) does not preclude the need of field studies - only in the field will epidemiological conditions be realistically experienced by the pathogen and the host. Nonetheless, previous studies using greenhousegrown plants, inoculation and assessments under controlled conditions are still useful in comparing germplasm response and particularly for understanding the basis of such resistance (32). Inoculating detached leaves can be a more rapid technique (32) of lower costs and higher throughput of test material, and it is not dependent on space limitations, compared with the greenhouse or field screening approaches. This method gives more rapid results, expediently identifying potential sources of resistance to ACC. Thus, in addition to field- and greenhousebased screening, these lab-based techniques have the potential to be a very useful tool for citrus-canker resistance breeding programs.
Stomata are known to be important entrance points for a large number of plant pathogenic bacteria (20). However, some evidence indicates that there is little relationship between the variability in susceptibility to ACC and the anatomy or number of stomata on the leaf (16), suggesting that resistance is mostly due to differences in bacterial growth after access to the leaf. However, recent studies have indicated that stomatal characteristics or other external characters might play a role in infection $(10,32)$. Information on stomatal characteristics of different Citrus species and varieties, combined with information on the relative susceptibility of the particular hosts based on wound inoculation will help provide further information about this potentially important aspect of host defense.

The aim of this study was to compare the resistance of different varieties of sweet orange to ACC by using a detached leaf technique combined with wound inoculation, as well as to investigate the morphological characteristics of the stomata in relation to the reported varietal resistance to ACC.

\section{MATERIAL AND METHODS}

\section{Sweet orange varieties and $X c c$ isolates}

Nine genotypes of sweet orange ( $C$. sinensis) were evaluated (Valencia Mutação, Castellana IVIA 64-3, Bey Navel, Washington Navel, Baia Leng, Pera IAC, Pera Ovo, Salustiana SPA 11, Khailily White). The Xcc isolate (Xcc 306) that was used for the inoculation of the test plants was obtained from the collection of plant pathogens "Fundo de Defesa da Citricultura" (Fundecitrus, Brazil), at the Molecular Laboratory of "Núcleo de Pesquisa em Biotecnologia Aplicada" (NBA) of Universidade Estadual de Maringá (UEM), Brazil.

Inoculum preparation, inoculation and evaluation of germplasm resistance

The detached leaves used in the experiment were collected from citrus plants located in an experimental orchard at the farm "Fazenda Experimental de Iguatemi” (FEI) (Latitude: $23^{\circ} 25^{\prime}$ S, Longitude: 52¹0’W; Altitude: 554.9), UEM, Maringá, Paraná, Brazil. The orchard had 213 citrus genotypes and was planted to assess varietal resistance to ACC. Genotypes were originally obtained from the Active Germplasm Bank (AGB) of "APTA Citros Sylvio Moreira" (CCSMIAC), Cordeirópolis, São Paulo, Brazil.

Prior to inoculation, shoots of the same maturity stage (when leaves were not hardened yet and $3 / 4$ fully expanded) and in good health conditions (no damage or symptoms of pathogens) were collected from the nine sweet orange varieties at FEI orchard. The shoots were sanitized and disinfected, by washing in $1 \%$ hypochlorite for five minutes, rinsed in sterile distilled water and allowed to dry. Leaves were removed from the shoots in a way that part of the petiole remained attached to the branch. Xcc was cultured on Nutrient agar (NA) medium in Petri plates placed in an incubator at $28^{\circ} \mathrm{C}$ for 72 hours before harvesting the colonies in sterile distilled water. The inoculum was adjusted to a concentration of $10^{8} \mathrm{CFU} /$ $\mathrm{mL}(2)$, using a spectrophotometer at a wavelength of $600 \mathrm{~nm}$ to adjust the concentration. Immediately after cutting from the shoot, the leaf was inoculated by wounding with a sterile needle $(20 \times 0.55$ $\mathrm{mm}$ ) which was dipped in the inoculum before wounding. Eight wounds were made per leaf ( 4 wounds on either side of the midrib) and a total of 10 leaves were wounded per variety. After inoculation, the leaves were placed in a Falcon tube $(50 \mathrm{ml})$ containing $1.5 \mathrm{ml}$ of water covering the stem section (which remained attached to 
the petiole) and half of the petiole, but without immersing the leaf surface. The tube cap was cracked so that the leaf could transpire. During the experiment, the water was replenished as needed to keep the environment moist and ensure the longevity of the leaf. The leaves were maintained at room temperature $\left(28^{\circ} \mathrm{C} 12 / 12\right.$ hours, night/day, respectively). The susceptibility of each genotype was evaluated by measuring the diameter of each of the eight lesions on the 10 replicate leaves by using a micrometer (IP67-Sylvac S.A., Crissier, Switzerland). Evaluations commenced at 7 days after inoculation (DAI), and two further assessments were performed at 10 and 13 DAI. The experiment was repeated once.

The results obtained for lesion diameter were subjected to analysis of variance (ANOVA) using the software SISVAR (System Analysis of Variance - v.5.6) (11). Data were normally distributed and exhibited homogeneity of variance. A Scott-Knott means separation test $(\alpha=0.05)$ was used to compare the mean diameters of lesions.

\section{Evaluation of infection and lesion development by Scanning Electron Microscopy (SEM)}

A morphological analysis of bacterial colonization and lesion structures was performed by using SEM with a Shimadzu SS550 SEM (Shimadzu do Brasil, São Paulo, Brazil), located at "Central de Microscopia" (CMI-COMCAP) of UEM. The samples were taken from two varieties - Pera IAC and Washington Navel (identified as most resistant and most susceptible in the first stage of this study, respectively). To obtain the lesions, the leaves were subjected to wound inoculation and incubated as described in the previous section by using an inoculum of $10^{8} \mathrm{CFU} / \mathrm{mL}$ (2). A spectrophotometer $(600 \mathrm{~nm})$ was used to adjust the concentration. Samples of the inoculated, symptomatic leaf material were obtained by excising the leaf section ( $5 \times 5 \mathrm{~mm}$, using a sterile scalpel) from the leaves at 3, 7, and 13 DAI.

To examine the developing ACC lesion on the leaf surface, leaf sections were taken from leaves in the same vegetative stage and physiological (hydration etc) and incubation conditions. The leaf sections were fixed with $2.5 \%$ glutaraldehyde at $4{ }^{\circ} \mathrm{C}$ for 24 $\mathrm{h}$, washed three times with $0.1 \mathrm{M}$ sodium cacodylate buffer, and dehydrated in an increasing ethanol gradient $(30,50,70,80,90,95$, $100 \%$ ethanol) for $10-15 \mathrm{~min}$ at each ethanol concentration. Critical point drying (with substitution of ethanol for $\mathrm{CO}_{2}$ ) was performed in a Balzers CPD 030 device (Bal-Tec, CPD 030, Leica Microsystems, Buffalo Grove, IL, USA). The samples were coated with gold (three cycles of $5 \mathrm{~min}$ at a $6 \mathrm{~mA}$ electric current) and observed under SEM. The stomatal morphology and bacterial colonization of the areas of interest were studied only for the abaxial leaf surface.

To examine symptom development inside the leaf after wound inoculation, the symptomatic plant tissue that was cut from the leaf was wrapped in parafilm and immersed in liquid nitrogen; immediately after removal from the liquid nitrogen, the lesion was transversely sectioned, using a sterile scalpel. Subsequently, samples were washed and dried according to the previously described methodology. To view the transversely sectioned face, samples were vertically arranged with the sectioned side facing up and coated with gold as described above.

After visualization of the stomata on the leaf surfaces, images were taken and the stomatal opening area of the two varieties was measured by using the KLONKimage Measurement V.13.2.2.213 (http://www. imagemeasurement.com/). Data were subjected to analysis of variance and means compared according to Tukey's HSD test $(\alpha=0.05)$.

\section{RESULTS}

In the first experiment, the leaves had senesced by 13 DAI, which precluded the measurements. In the second experiment, the leaves remained sufficiently healthy to obtain measurements at 13 DAI.

\section{Citrus genotypes and $X c c$ isolates}

Symptoms of ACC began to develop at 7 DAI on the $\mathrm{Xcc}$-inoculated detached leaves maintained in Falcon tubes. Lesions first developed on the abaxial side of the leaves as white, spongy, protruding pustules, and by the end of the experiment (13 DAI) the lesions had developed through the leaf to the adaxial surface and were thickened and had darkened to brown to light brown color. All varieties developed typical ACC lesions.

Considering the 9 varieties in the inoculation test, there were significant differences in lesion size among varieties in Experiment $1($ F-value $=31.3$ and 16.6; P-values $<0.0001$ at 7 and 10 DAI, respectively) (Table 1) and in Experiment 2 (F-value $=33.1,14.0$ and 13.6; P-values $<0.0001$ at 7,10 and $13 \mathrm{DAI}$, respectively). Scott-Knott test and ranking order for lesion size for each sample after inoculation in both Experiments 1 and 2 showed Pera IAC was most often the most resistant variety (only in Experiment 2, at 10 DAI, it was ranked '2' but was not significantly different from the most resistant variety on that date - Khalily White). Similarly, Washington Navel was most often the most susceptible variety (only in Experiment 2, at 10 DAI, it was ranked ' 7 ' but was not significantly different from the most susceptible variety on that date-Valencia Mutação). Ranking of other varieties also varied with the sample date, although the ranking was most often within three positions from the other sample dates in both experiments. There was variability in lesion size. For each variety, the mean lesion size was larger or smaller with later sample dates, suggesting there was little change in lesion size between 7 and $13 \mathrm{DAI}$ and that the measurements of the lesions were perhaps affected by the plane chosen to determine the diameter (measurement across the same plane did not include each of the 8 lesions on the sample leaves every time). Furthermore, a minor error in defining where a lesion begins and ends, in relation to healthy tissue, could change the measurements in mm fractions, as observed for these data, leading to variability in measurements with time.

Evaluation of infection and symptom development by using Scanning Electron Microscopy (SEM)

There was no significant difference $(\mathrm{F}$-value $=5.0, \mathrm{P}=0.09)$ in stomatal density on the abaxial surface between the varieties Pera IAC and Washington Navel, based on the analysis of SEM images (Figure 1 $\mathrm{A}, \mathrm{B}$ and $\mathrm{E})$. In contrast, there were significant differences ( $\mathrm{F}$-value $=$ $45.7, \mathrm{P}=0.0001)$ in the mean area of stomatal aperture on the abaxial surface between the two genotypes; the variety Pera IAC had smaller area of stomatal aperture, compared to those of the variety Washington Navel (Figure $1 \mathrm{C}, \mathrm{D}$ and F).

SEM images of the leaves following wound inoculation with Xcc showed that, at 3 DAI, bacterial colonization of the leaves differed between the two varieties. Presence of an extracellular matrix near the lesion was more evident on leaves of the variety Pera IAC (Figure 2, A and B). This extracellular matrix appeared to coat the bacteria. Washington Navel, at 3 DAI, showed increased surface colonization by $X c c$, with apparent pathogen entry through the stomatal aperture, compared with Pera IAC. At 7 DAI, it was still possible to discern the reduced colonization by $X c c$ around the stomatal opening on leaves of Pera IAC, which showed the presence of extracellular matrix. At 7 DAI, there were a greater number of bacterial clusters on the leaves of 
Table 1. Diameter of ACC lesions on detached Citrus leaves in two experiments (A and B) of nine different sweet orange varieties inoculated with Xcc by using the needle-wounding technique. The lesions were measured at 7, 10 and 13 days after inoculation.

A. Experiment 1

\begin{tabular}{|c|c|c|c|c|c|c|c|c|}
\hline \multirow{2}{*}{ Genotype } & \multicolumn{2}{|l|}{ Day 7} & \multicolumn{2}{|l|}{ Day 10} & \multicolumn{2}{|c|}{ Day 13} & \multicolumn{2}{|c|}{ Mean of all evaluations } \\
\hline & Mean $^{1}$ & Numerical ranking $^{2}$ & Mean & Numerical ranking & Mean & Numerical ranking & Mean & Numerical ranking \\
\hline Bey Navel & $1.503 \mathrm{c}$ & 6 & $1.764 \mathrm{c}$ & 8 & -3 & & 1.634 & 8 \\
\hline Castellana Ivia & $1.553 \mathrm{c}$ & 7 & $1.503 \mathrm{~b}$ & 4 & & & 1.528 & 5 \\
\hline Baia Leng & $1.371 \mathrm{~b}$ & 3 & $1.467 \mathrm{~b}$ & 3 & & & 1.419 & 2 \\
\hline Pera Ovo & $1.362 \mathrm{~b}$ & 2 & $1.551 \mathrm{~b}$ & 5 & & & 1.457 & 3 \\
\hline Valencia Mutação & $1.495 \mathrm{c}$ & 5 & $1.580 \mathrm{~b}$ & 7 & & & 1.538 & 6 \\
\hline Washington Navel & $1.834 \mathrm{~d}$ & 9 & $1.795 \mathrm{c}$ & 9 & & & 1.815 & 9 \\
\hline Pera IAC & $1.078 \mathrm{a}$ & 1 & $1.348 \mathrm{a}$ & 1 & & & 1.213 & 1 \\
\hline Salustiana SPA 11 & $1.394 \mathrm{~b}$ & 4 & $1.560 \mathrm{~b}$ & 6 & & & 1.477 & 4 \\
\hline Khailily White & $1.751 \mathrm{~d}$ & 8 & $1.404 \mathrm{a}$ & 2 & & & 1.578 & 7 \\
\hline Mean & 1.482 & & 1.552 & & & & 1.517 & \\
\hline $\mathrm{CV} \%$ & 8.08 & & 7.08 & & - & & & \\
\hline $\mathrm{F}$ & 31.3 & & 16.6 & & - & & & \\
\hline P-value & $<0.0001$ & & $<0.0001$ & & - & & & \\
\hline
\end{tabular}

\section{B. Experiment 2}

\begin{tabular}{|c|c|c|c|c|c|c|c|c|}
\hline \multirow[t]{2}{*}{ Genotype } & \multicolumn{2}{|l|}{ Day 7} & \multicolumn{2}{|l|}{ Day 10} & \multicolumn{2}{|l|}{ Day 13} & \multicolumn{2}{|c|}{ Mean of all evaluations } \\
\hline & Mean & Numerical ranking & Mean & Numerical ranking & Mean & Numerical ranking & Mean & Numerical ranking \\
\hline Bey Navel & $1.876 \mathrm{~d}$ & 8 & $1.48 \mathrm{~b}$ & 3 & $1.563 \mathrm{~b}$ & 3 & 1.640 & 7 \\
\hline Castellana Ivia & $1.674 \mathrm{c}$ & 6 & $1.546 \mathrm{~b}$ & 5 & $1.639 \mathrm{~b}$ & 6 & 1.620 & 6 \\
\hline Baia Leng & $1.426 \mathrm{a}$ & 3 & $1.521 \mathrm{~b}$ & 4 & $1.741 \mathrm{~b}$ & 8 & 1.563 & 4 \\
\hline Pera Ovo & $1.378 \mathrm{a}$ & 2 & $1.587 \mathrm{c}$ & 6 & $1.598 \mathrm{~b}$ & 4 & 1.521 & 3 \\
\hline Valencia Mutação & $1.579 \mathrm{~b}$ & 5 & $1.725 \mathrm{c}$ & 9 & $1.634 \mathrm{~b}$ & 5 & 1.646 & 8 \\
\hline Washington Navel & $1.926 \mathrm{~d}$ & 9 & $1.666 \mathrm{c}$ & 7 & $1.923 \mathrm{c}$ & 9 & 1.838 & 9 \\
\hline Pera IAC & $1.373 \mathrm{a}$ & 1 & $1.359 \mathrm{a}$ & 2 & $1.218 \mathrm{a}$ & 1 & 1.317 & 1 \\
\hline Salustiana SPA 11 & $1.451 \mathrm{a}$ & 4 & $1.693 \mathrm{c}$ & 8 & $1.695 \mathrm{~b}$ & 7 & 1.613 & 5 \\
\hline Khailily White & $1.727 \mathrm{c}$ & 7 & $1.340 \mathrm{a}$ & 1 & $1.366 \mathrm{c}$ & 2 & 1.478 & 2 \\
\hline Mean & 1.601 & & 1.546 & & 1.597 & & 1.582 & \\
\hline $\mathrm{CV} \%$ & 7.26 & & 7.53 & & 11.05 & & & \\
\hline $\mathrm{F}$ & 33.1 & & 14.0 & & 13.6 & & & \\
\hline P-value & $<0.0001$ & & $<0.0001$ & & $<0.0001$ & & & \\
\hline
\end{tabular}

${ }^{1}$ Averages in columns followed by different letters are significantly different based on the Scott-Knott means separation test $(\alpha=0.05)$.

${ }^{2}$ The numerical ranking is the susceptibility of the variety ranked 1 (most resistant) to 9 (most susceptible) at each assessment date for each experiment.

${ }^{3}$ Missing values. In the first experiment many leaves had senesced at the time of the $13^{\text {th }}$ day of assessment.

Washington Navel, which formed small colonies on the leaf surface (Figure 2, C and D).

At 14 DAI, symptoms of ACC were clearly evident, especially on the leaves of the susceptible variety Washington Navel, compared to the leaves of the resistant variety Pera IAC (Figure 2, E and F, respectively). At 14 DAI, the images of lesion cross-sections indicated that a more substantial biofilm formed on leaves of the variety Washington Navel, and small colonies developed, occupying the intercellular space among the parenchyma cells, compared to leaves of Pera IAC (Figure 2, G and $\mathrm{H}$, respectively).

The injuries caused by the needle piercing in the inoculation process were clearly visible in the SEMs (Figure 3), as well as the resulting distribution of $X c c$ associated with the infection process. The distribution of the bacteria suggests that they aggregate or form small sub-colonies, which appear to grow or clump together.

\section{DISCUSSION}

The first symptoms of ACC were noticeable at 7 DAI. In similar tests using detached leaves, Deng et al. (9) first detected symptoms between 3 and 10 DAI, but Wang et al. (32) observed small circular lesions that developed on the abaxial surface of the leaves as early as 3 DAI. The symptoms we observed are in accordance with these prior reports. In a previous study, 582 citrus accessions were evaluated for ACC resistance under greenhouse conditions using spray inoculation (1). The lesion area was measured and resistance classified according to Hammerschlag (19), grouping responses as resistant (0-5\% diseased leaf 
Pera IAC
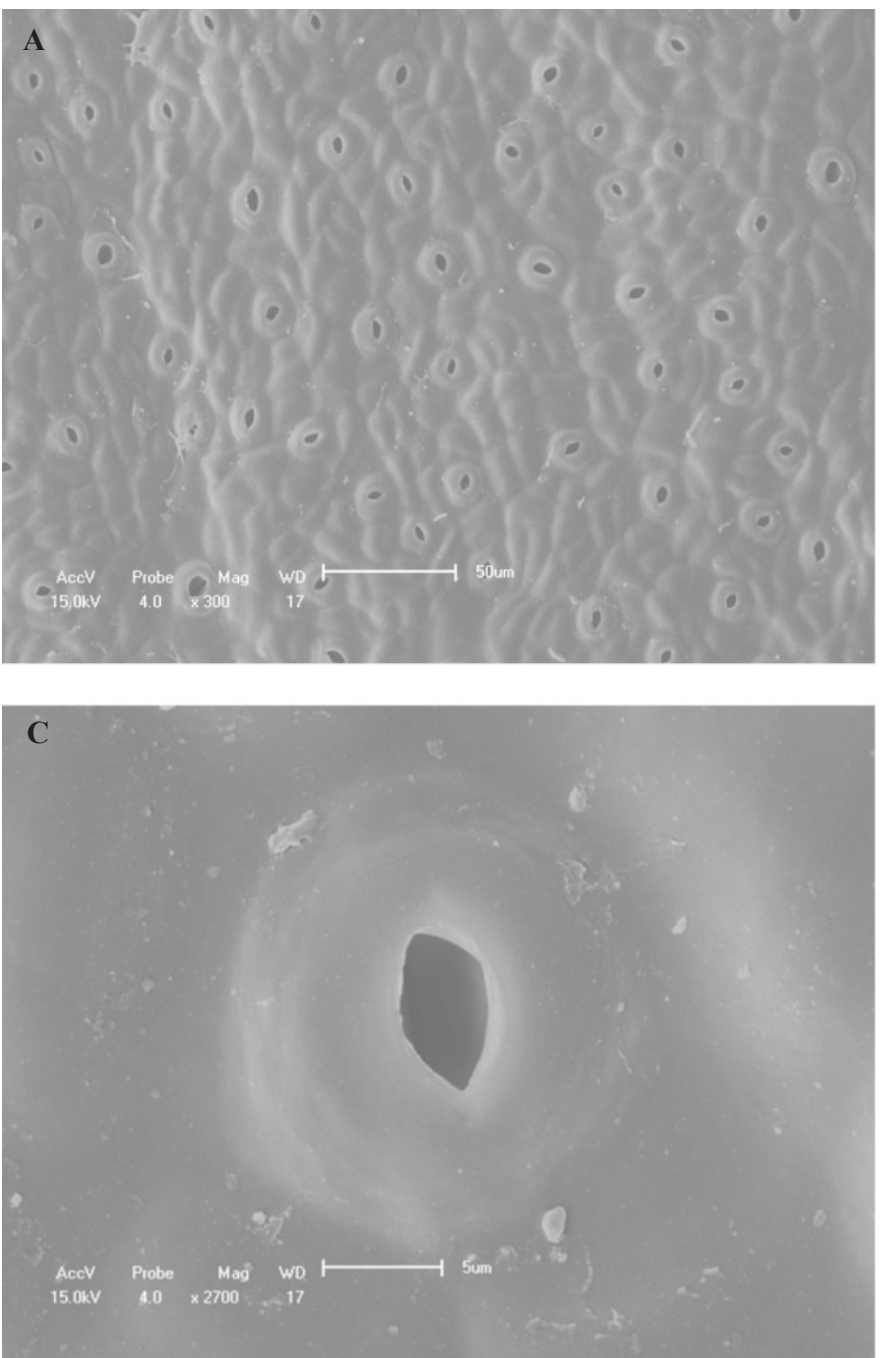

$\mathbf{E}$

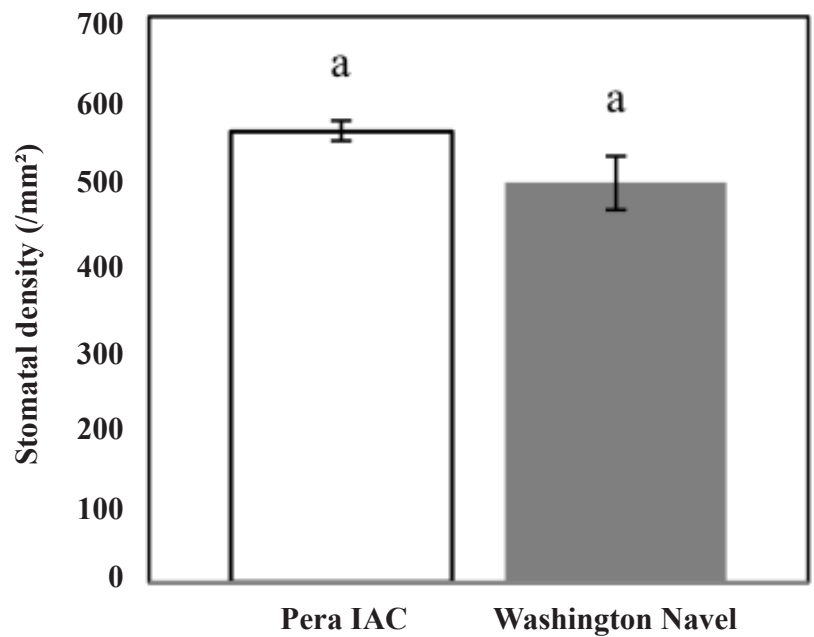

Washington Navel
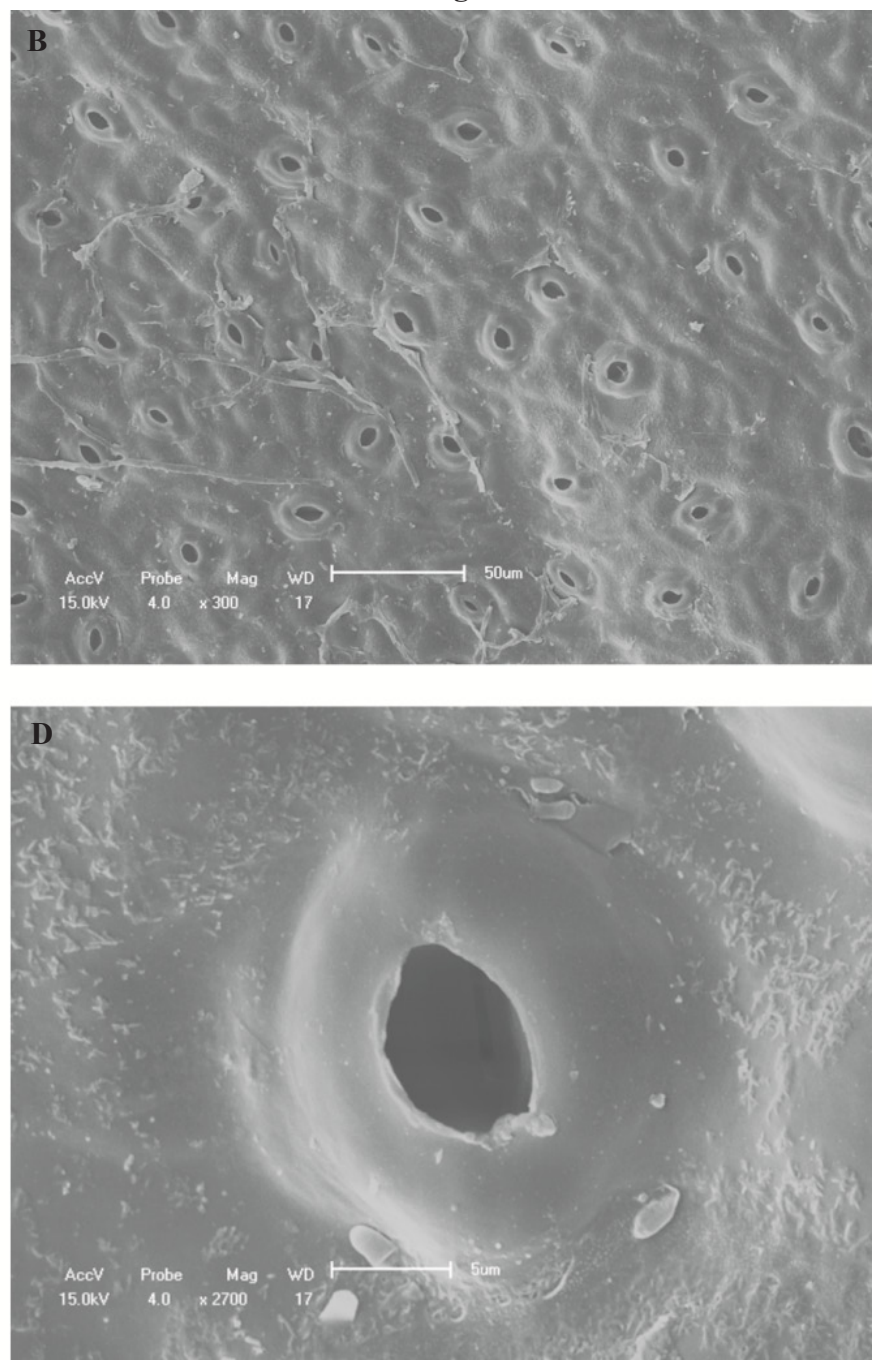

$\mathbf{F}$

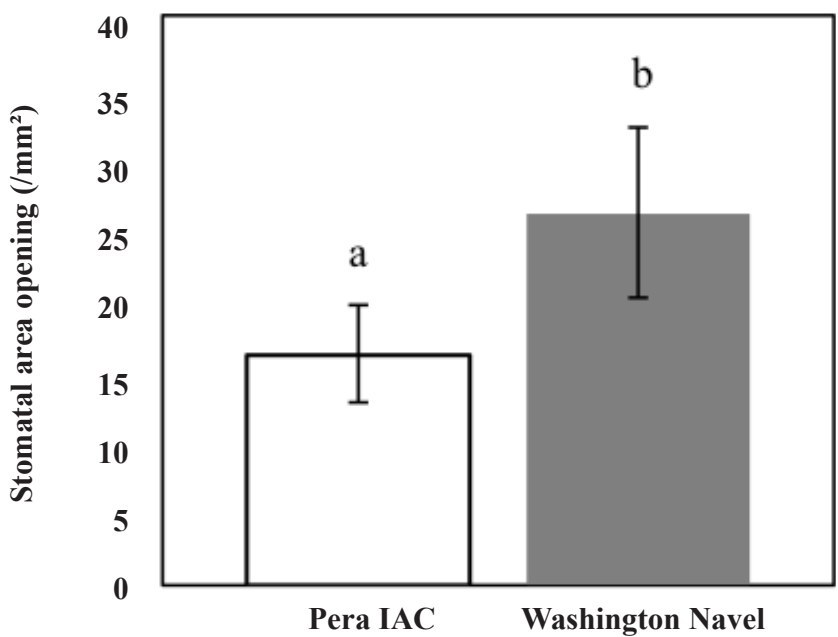

Figure 1. Comparison of stomatal characteristics on the abaxial surface of sweet orange varieties Pera IAC and Washington Navel prior to inoculation with $X$. citri. Representative images showing distribution and numbers of stomata by SEM (A and B, respectively) at $300 \times$ magnification. Representative images showing individual stomatal apertures of Pera IAC and Washington Navel (C and D, respectively) at 2700× magnification. The density and mean area of the stomatal apertures in Pera IAC and Washington Navel are shown in E and F, respectively. Means with different letters are significantly different based on Tukey's HSD test $(\alpha=0.05)$. For comparison of stomatal density, F-value $=5.0$, P-value $=0.09$ (coefficient of variation $=9.55 \%)$; and for comparison of stomatal aperture area, F-value $=45.7, \mathrm{P}<0.0001$ (coefficient of variation $=45.80 \%$ ). 
Pera IAC


Washington Navel


Figure 2. Comparison of colonization and infection at the wound inoculation site on the abaxial surface of sweet orange varieties Pera IAC and Washington Navel after inoculation with $X$. citri and visualized using Scanning Electron Microscopy. Representative images of the stomatal apertures on the leaf surfaces colonized by $X$. citri at 3 days after inoculation (DAI) (A and B, respectively), 2700× magnification. Representative images of the stomatal apertures on leaf surfaces colonized by $X$. citri at 7 DAI (C and D, respectively), 2700× magnification. Representative images of the lesion development site at 14 DAI with $X$. citri (E and F, respectively), 40× magnification. Representative images of leaf injury associated with symptoms of ACC resulting from wound inoculation as shown in the cross section of the leaves with bacteria of $X$. citri evident at $14 \mathrm{DAI}$ ( $\mathrm{G}$ and $\mathrm{H}$, respectively), 1800× magnification. 

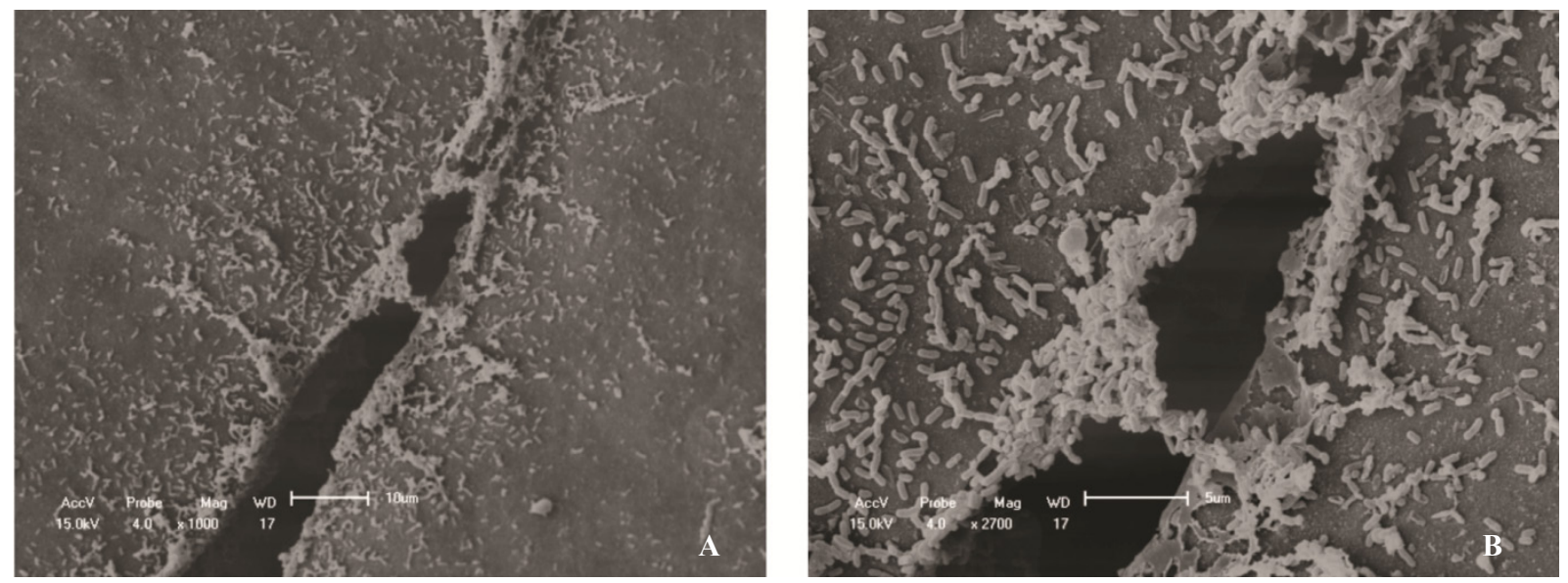

Figure 3. Representative images of the injury caused by the needle puncture inoculation method on the abaxial surface of a leaf of the sweet orange variety Pera IAC at 3 days after inoculation at (A) $1000 \times$ magnification and at (B) $2700 \times$ magnification.

area), moderately resistant (5-10\%), susceptible (10-15\%) and highly susceptible (>15\%). In that study, the accessions Baia Leng, Castellana Ivia 64-3, Khailily White, Pera IAC and Pera Ovo were clustered as moderately resistant, whereas Salustiana SPA 11 and Valencia Mutação were classified as susceptible, and Washington Navel was classified as highly susceptible. Although the methods for inoculation and symptom assessments were contrasting between the present study and that of Amaral et al. (1), there is a general agreement in ranking - the smallest lesions were most frequently present in Pera IAC, Khailily White and Pera Ovo (suggesting they are more resistant to $X c c$ ), which is also in agreement with the results of Gonçalves-Zuliani et al. (12). Amaral et al. (1) classified Salustiana SPA 11 and Valencia Mutação as susceptible; they also found these varieties were more susceptible than the others based on lesion diameter. Washington Navel was ranked as highly susceptible, and it also had the largest lesions, compared with the other varieties. Other field experiment-based observations of ACC severity indicated that the relative susceptibilities of these 9 varieties are similar to our findings (except for Valencia Mutação as its lesions were larger than those of Pera IAC) (30).

Thus, using needle-wound inoculation of detached leaves to evaluate resistance to ACC can result in relative varietal disease severities similar to those observed for plants inoculated by spraying and grown under greenhouse conditions, as well as naturally infected plants grown in the field. Wounding has been used in the assessment of varietal resistance to ACC and in various epidemiological studies $(3,15)$ but allows $X c c$ to bypass resistance mechanisms, including the cuticle (18) that exists on a non-injured leaf (10). Vernière et al. (31) noted that wounding and inoculation of plant material resulted in ACC symptoms more rapidly and more uniformly expressed, compared with inoculation of intact tissues. Secondary resistance occurs in the mesophyll (28), and the results we present suggesting differences in lesion size among varieties of sweet orange after wound inoculation likely relate to internal resistance mechanisms in the leaf. It is important to note that the inoculum concentration of Xcc used in this study $\left(10^{8}\right.$ $\mathrm{CFU} / \mathrm{mL}$ ) guaranteed the development of typical ACC symptoms and that wounds guaranteed access to the interior of the leaf- although we were still capable of discerning between differential host responses, further indicating that resistance mechanisms occur inside the leaf.

We found that the lesion sizes on detached leaves varied over the experiment (up to $13 \mathrm{DAI}$ ); furthermore, although the actual differences between lesion sizes on the different varieties of sweet orange were significant, they were small. In a previous study, lesion size showed substantial differences among different species and hybrids of Citrus up to 60 days after pinprick inoculation of attached leaves (14) but negligible differences among the screened varieties of sweet orange. Our results bear out that observation: the differences in lesion size of the screened sweet orange varieties were subtle, although statistically discernible.

Considering that stomata are an important route for infection (16) and Pera IAC and Washington Navel varieties showed the greatest contrast in levels of resistance to wound inoculation (suggesting resistance mechanisms inside the leaf), we also compared the morphologies of the leaf surfaces of both varieties by using SEM to verify whether there were any differences in morphology between the two contrasting varieties. In an earlier study using SEM (32), stomatal density and size were compared between the most resistant citrus variety Meiwa (Fortunella crassifolia) and the most susceptible variety Newhall of navel orange (C. sinensis). Meiwa had lower density and stomatal size, compared to Newhall; larger stomata might allow easier bacterial access into the leaf, explaining the greater resistance of Meiwa, compared to Newhall. Although we did not directly compare susceptibility through stomatal entry of $X c c$, the smaller stomatal aperture of Pêra IAC may be indicative of a resulting physical defense barrier in addition to internal resistance mechanisms that lead to lower susceptibility in this variety.

The extracellular matrix observed around the stomatal apertures at 3 and 7 DAI may be related to resistance to ACC. Previous studies have indicated that the ACC-resistant species Kumquat [F. margarita (Lour.) Swingle] and Calamondin [C. mitis (Blanco)] showed brighter fluorescence associated with necrotic lesions when observed under a fluorescence microscope, compared to that observed for ACCsusceptible Mexican lime [C. aurantifolia (Swingle)] (6). The authors suggest that the brighter fluorescence could be due to the accumulation of various defense molecules, lignification of the cell wall and/or production of hydrogen peroxide $\left(\mathrm{H}_{2} \mathrm{O}_{2}\right)$, thereby reducing lesion development in the resistant germplasm. Hydrogen peroxide is thought to be involved in plant defense against pathogens, either by influencing the hypersensitive response, which aids in the cell death process or in regulating stomatal movement (6). In addition, Chen et al. (6) observed a large number of bacteria along the edges of Mexican lime leaf discs but only a few bacteria on the edges of discs from Calamondin and Kumquat. They suggested that the presence of toxic elements in Calamondin and Kumquat inhibited Xcc growth and colonization - and this finding may be in accordance with our observation that there were 
fewer bacteria around stomata of Pera IAC, compared with Washington Navel. Furthermore, inoculation by needle injury may have caused release of $X c c$-toxic compounds reducing colonization and development in Pera IAC. Absence of toxic substances released by Washington Navel may have favored formation of a biofilm, resulting in the small colonies of $X c c$ observed at 7 DAI. Biofilms protect bacteria from environmental stresses, host defense mechanisms and antimicrobial compounds (24). Rigano et al. (25) characterized biofilm development in Xcc, which occurs first through the binding of bacteria that aggregate or form small colonies, resulting in structured biofilms (as we observed), as has also been previously commented (23). Recently, Favaro et al. (10) reported reduced biofilm formation with $X c c$ in a more resistant citrus species (C. unshiu Marc. cv. Aoshima), compared to a more susceptible one (C. clementina Hort. ex Tanaka), and found that structural features of the leaf, such as the cuticle, might also be involved in resistance. More detailed physiological studies are needed to clarify the origin and nature of the extracellular metabolites produced by the host and those associated with $X c c$.

In conclusion, the detached leaf/wound inoculation assay is a tool that has some value to compare the resistance to ACC of citrus genotypes and to study the infection process. Although detached leaf assays are of short duration, low cost and high throughput (32), the issue of leaf survival might preclude easily assessing differences in mature lesion size. Observation of the differences in colonization between resistant and susceptible genotypes using SEM can further elucidate the differences in ACC symptom development. Further research is needed to determine the extracellular compounds produced by the host that might be involved in antibiotic activity and that might be of interest in citrus breeding programs.

\section{ACKNOWLEDGEMENTS}

We thank the National Council for Scientific and Technological Development - CNPq, for part of the financial support. The study was also supported by grants from the Coordination for the Improvement of Higher Education Personnel - CAPES. A. M. O. Gonçalves-Zuliani was the recipient of the CAPES grants. J. Belasque Jr, C.V. Nakamura and W.M.C. Nunes received a fellowship from CNPq.

\section{REFERENCES}

1. Amaral, A.M.; Carvalho, S.A.; Silva, L.F.C.; Machado, M.A. Reaction of genotypes of citrus species and varieties to Xanthomonas citri subsp. citri under Greenhouse conditions. Journal of Plant Pathology, Bari, v.92, p.519-524, 2010.

2. Belasque Jr, J.; Jesus Jr, W.C. Concentração de inoculo e método de inoculação de Xanthomonas axonopodis pv. citri. Laranja, Cordeirópolis, v.27, p.263-272, 2006.

3. Belasque Jr, J.; Jaciani, F.J.; Marin, D.R.; Barbosa, J.C. Tamanho da amostra para quantificação do diâmetro de lesões de cancro cítrico. Tropical Plant Pathology, Lavras, v.33, p.317-322, 2008.

4. Behlau, F.; Belasque Jr, J.; Graham, J.H.; Leite Jr, R.P. Effect of frequency of copper applications on control of citrus canker and the yield of young bearing sweet orange trees. Crop Protection, Lincoln, v.29, p.300-305, 2010.

5. Bock, C.H.; Graham, J.H.; Gottwald, T.R.; Cook, A.Z.; Parker, P.E. Wind speed and wind-associated leaf injury affect severity of citrus canker on Swingle citrumelo. Europe Journal of Plant Pathology, Wageningen, v.128, p.21-38, 2010.

6. Chen, P.S.; Wang, L.Y.; Chen, Y.J.; Tzeng, K.C.; Chang, S.C.; Chung, K.R.; Lee, M.H. Understanding cellular defence in kumquat and calamondin to citrus canker caused by Xanthomonas citri subsp. citri. Physiological and Molecular Plant Pathology, London, v.79, p.1-12, 2012.
7. Carvalho, S.A.; Nunes, W.M.C.; Belasque Jr, J.; Machado, M.A.; CroceFilho, J.; Bock, C.H.; Abdo, Z. A comparison of resistance to Asiatic citrus canker among different genotypes of Citrus spp. in a long-term cankerresistance field screening experiment in Brazil. Plant Disease, Saint Paul, v.99, p.207-218, 2014.

8. Dalla-Pria, M.; Christiano, R.C.S.; Furtado, E.L.; Amorim, L.; Bergamin Filho, A. Effect of temperature and leaf wetness duration on infection of sweet oranges by Asiatic citrus canker. Plant Pathology, Oxford, v.55, p.657-663, 2006.

9. Deng, Z.N.; Xu, L.; Li, D.Z.; Long, G.Y.; Liu, L.P.; Fang, F.; Shu, G.P. Screening citrus genotypes for resistance to canker disease (Xanthomonas axonopodis pv. citri). Plant Breeding, Berlin, v.129, p.341-345, 2010.

10. Favaro, M.A.; Micheloud, N.G.; Roeschlin, R.A.; Chiesa, M.A.; Castagnaro, A.P.; Vojnov, A.A.; Gmitter Jr, F.G.; Gadea, J.; Rista, L.M.; Gariglio, N.F.; Marano, M.R. Surface barriers of mandarin 'Okitsu' leaves make a major contribution to canker disease resistance. Phytopathology, Saint Paul, v.104, p.970-976, 2014.

11. Ferreira, D.F. Sisvar: a computer statistical analysis system. Ciência e Agrotecnologia, Lavras, v. 35, n.6, p. 1039-1042, 2011.

12. Gonçalves-Zuliani, A.M.O.; Belasque Jr, J.; Zanutto, C.A.; Remolli, J.A.; Nunes, W.M.C. Resistance of 'Pêra' sweet orange (Citrus sinensis) genotypes to Xanthomonas citri subsp. citri in field conditions. Workshop on Xanthomonas citri/Citrus canker, Ribeirão Preto, p. 78-80, 2011.

13. Gottwald, T.R.; Graham, J.H.; Bock, C.H.; Bonn, G.; Civerolo, E.L.; Irey, M.; Leite, R.; Lopez, M.; Mccollum, T.G.; Parker, P.; Ramallo, J.; Riley, T.; Schubert, T.; Stein, B.; Taylor, E.L. The epidemiological significance of post-packinghouse survival of Xanthomonas citri ssp. citri for dissemination of Asiatic citrus canker via infected fruit. Crop Protection, Linconl, v.29, p.508-524, 2009.

14. Gottwald, T.R.; Graham, J.H.; Civerolo, E.L.; Barrett, H.C.; Hearn, C.J.Differential host range reaction of citrus and citrus relatives to citrus canker and citrus bacterial spot determined by leaf mesophyll susceptibility. Plant Disease, Saint Paul, v.77, p.1004-1009, 1993.

15. Gottwald, T.R.; Graham, J.H. A device for precise and nondisruptive stomatal inoculation of leaf tissue with bacterial pathogens. Phytopathology, Saint Paul, v.82, p.930-935, 1992.

16. Graham, J.H.; Gottwald, T.R.; Riley, T.D.; Achor, D. Penetration through leaf stomata and growth of strains of Xanthomonas campestris in citrus cultivars varying in susceptibility to bacterial diseases. Phytopathology, Saint Paul, v.82, p.1319-1325, 1992.

17. Graham, J.H.; Gruber, B.; Bock, C.H. Research progress for integrated management of citrus canker. Citrus Industry, Gainesville, v.93, p.2024, 2013.

18. Graham, J.H.; Gottwald, T.R.; Cubero, J.; Achor, D.S. Xanthomonas axonopodis pv. citri: factors affecting successful eradication of citrus canker. Molecular Plant Pathology, Malden, v.5, p.1-15, 2004.

19. Hammerschlag, F.A. Resistance responses of plants regenerated from peach callus to Xanthomonas campestris pv. pruni. Journal of American Society Horticulture Science, Alexandria, v.115, p.1034-1037, 1990.

20. Hung, J.S. Ultrastructure of bacterial penetration in plants. Annual Review of Phytopathology, Palo Alto, v.24, p.141-157, 1986.

21. Koizumi, M. Relationship between wound-healing process of citrus leaf tissues and their successful infection through wounds by Xanthomonas campestris pv. Citri (Hasse) Dye. Annals of the Phytopathological Society Japan, Tokyo, v.49, p.352-360, 1983.

22. Massari, CA, Belasque Jr. J ( 2006) A campanha de erradicação do cancro cítrico no Estado de São P aulo - Situação atual e contaminação em viveiros . Laranja, Cordeirópolis, 27:41- 55.

23. Oliveira, A.G.; Murate, L.S.; Spago, F.R.; Lopes, L.P.; Beranger, J.P.O.; San Martin, J.A.B.; Nogueira, M.A.; Mello, J.C.P.; Andrade, C.G.T.J.; Andrade, G. Evaluation of the antibiotic activity of extracellular compounds produced by the Pseudomonas strain against the Xanthomonas citripv. citri 306 strain. Biological Control, San Diego, v.56, p.125-131, 2011.

24. O’Toole, G.; Kaplan, H.B.; Kolter, R. Biofilm formation as microbial devele opment. Annual Review of Microbiology, Palo Alto, v.54, p.49-79, 2000.

25. Rigano, L.A.; Siciliano, F.; Enrique, R.; Sendin, L.; Filippone, P.; Torres, P.S.; Questa, J.; Dow, J.M.; Castagnaro, A.P.; Vojnov, A.A.; Marano, M.R. Biofilm formation, epiphytic fitness, and canker development in Xanthomonas axonopodis pv. citri. Molecular Plant-Microbe Interactions, St. Paul, v.20, p.1222-1230, 2007.

26. Schaad NW, Postnikova E, Lacy GH, et al: Emended classification of xan- 
thomonad pathogens on citrus. Systematic and Applied Microbiology, Stuttgart, 2006, 29:690-695.

27. Schubert, T.S.; Rizvi, S.A.; Sun, X.; Gottwald, T.R.; Graham, J.H.; Dixon, W.N. Meeting the challenge of eradicating citrus canker in Florida-Again. Plant Disease, Saint Paul, v.85, p.340-356, 2001.

28. Stall, R.E.; Marcó, G.M.; Canteros de Echenique, B.I. Importance of mesophyll in mature-leaf resistance to cancrosis of citrus. Phytopathology, Saint Paul, v.72, p.1097-1100, 1982.

29. Stover, E.; Driggers, R.; Richardson, M.L.; Hall, D.G.; Duan, Y. Incidence and severity of Asiatic citrus canker on diverse Citrus and Citrus-related germplasm in a Florida field planting. HortScience, Alexadria, v.49, p.49, 2014.
30. Vargas, R.G.; Gonçalves-Zuliani, A.M.O.; Croce Filho, J.; Carvalho, S.A.; Nocchi, P.T.R.; Nunes, W.M.C. Avaliação da resistência de variedades de Citrus spp. à Xanthomonas citri subsp. citri na região Noroeste Paranaense, em condições de campo. Summa Phytopathologica, Botucatu, v.39, p. 235-241, 2013

31. Vernière, C.J.; Gottwald, T.R.; Pruvost, O. Disease development and symptom expression of Xanthomonas axonopodis pv. citri in various citrus plan tissues. Phytopathology, Saint Paul, v.93, p.832-843, 2003.

32. Wang, Y.; Fu, X.Z.; Liu, J.H.; Hong, N. Differential structure and physiological response to canker challenge between Meiwa kumquat and Newhal navel orange with contrasting resistance. Scientia Horticulturae, Amsterdam, v.128, p.115-123, 2011. 